\title{
Long-chain inulin increases dendritic cells in the Peyer's patches and increases ex vivo cytokine secretion in the spleen and mesenteric lymph nodes of growing female rats, independent of zinc status
}

\author{
Natasha R. Ryz ${ }^{1}$, Jon B. Meddings ${ }^{2}$ and Carla G. Taylor ${ }^{1} *$ \\ ${ }^{1}$ Department of Human Nutritional Sciences, University of Manitoba, H507 Duff Roblin Building, Winnipeg MB R3T 2N2, Canada \\ ${ }^{2}$ Division of Gastroenterology, Department of Medicine, University of Alberta, Edmonton AB T6G 2E1, Canada \\ (Received 29 April 2008 - Revised 15 September 2008 - Accepted 15 September 2008 - First published online 24 November 2008)
}

Prebiotics may increase $\mathrm{Zn}$ absorption, a mineral known to play a central role in the immune system. Zn-deficient states are characterised by suppressed immune function, while prebiotics may improve both gut and cell-mediated immunity. Our objective was to determine if inulin alters the number and proportion of immune cells in the spleen, mesenteric lymph nodes (MLN) and Peyer's patches (PP), ex vivo cytokine secretion, intestinal permeability and $\mathrm{Zn}$ status in healthy as well as Zn-deficient rats. Weanling female rats were fed diets supplemented with $5 \%$ cellulose (CEL) or $5 \%$ inulin (PRE) for 4 weeks. The rats received the CEL or PRE diet ad libitum (ZN) or in restricted amounts (DR), or deficient in Zn (ZD) for another 4 weeks. The PRE-fed rats had a higher number and proportion of dendritic cells in PP, and greater ex vivo secretion of IL-2, IL-10 and interferon- $\gamma$ from spleen and MLN cells compared with CEL-fed rats. PRE reduced the number and proportion of T cell receptor (TCR)- $\alpha \beta^{+} \mathrm{CD} 8^{+}$cells in spleen and CD45RA ${ }^{+}$cells in MLN compared with CEL. ZD rats had lower serum IgG2a and T cell numbers in MLN compared with ZN and DR rats. $\mathrm{TCR} \gamma \delta^{+}$cell numbers in PP were higher in ZD-PRE rats compared with ZD-CEL rats. Femur Zn concentrations of DR-PRE rats were higher than those of DR-CEL rats. Intestinal permeability was unchanged. The higher proportion and number of dendritic cells in the PP of inulin-fed rats indicates a need for further research on how prebiotics and their metabolites affect immune function possibly through intestinal dendritic cells.

Inulin: Zinc deficiency: Cytokines: Dendritic cells: Rats

Inulin-type fructans, including inulin, oligofructose and synthetic fructo-oligosaccharides (FOS) are considered prebiotics, which are defined as non-digestible food ingredients that selectively stimulate the growth, composition and/or activity of health-promoting bacteria already present in the colon ${ }^{(1)}$. In rodent models, prebiotics have been shown to enhance the thickness of the epithelial mucus layer ${ }^{(2)}$, and increase the proportion of lymphocytes and increase ex vivo cytokine secretion in the gut-associated lymphoid tissue ${ }^{(3-6)}$. Furthermore, prebiotics have been shown to increase the proportion of dendritic cells in the lamina propria of patients with Crohn's disease ${ }^{(7)}$.

Dendritic cells play an important link between the innate and acquired immune systems. The major function of dendritic cells is to process and present antigens to $\mathrm{CD} 4^{+} \mathrm{T}$ helper cells (Th) in a stimulatory or tolerogenic fashion ${ }^{(8)}$. Activated Th can differentiate into Th1 or Th2 cells depending on the type of antigen and cytokines that they encounter ${ }^{(9)}$. Viruses and bacteria influence naive $\mathrm{T}$ cells to become Th1 cells, which drive cell-mediated immunity. Th1 cells secrete the cytokines IL-2 and interferon- $\gamma$ (IFN- $\gamma$ ), which activate $\mathrm{CD}^{+}$cytotoxic $\mathrm{T}$ cells and induce antibody-class switching to $\operatorname{IgG} 2 \mathrm{a}^{(10)}$. Allergens and parasites favour the Th2 pathway, which is essential for humoral immunity and promoting antibody-class switching to $\operatorname{IgG} 1^{(9)}$. Tolerogenic responses are attributed to regulatory $\mathrm{T}$-cells $\left(\mathrm{T}_{\mathrm{reg}}\right)$ which are important in the presence of dietary antigens and commensal bacteria ${ }^{(8)}$. $\mathrm{T}_{\text {reg }}$ secrete cytokines such as IL-10, which suppress the activation of Th1 and Th2 cells ${ }^{(11)}$.

Initial studies show that prebiotics may increase the absorption of $\mathrm{Zn}^{(12,13)}$, a mineral known to play a central role in the immune system. Clinical manifestations of $\mathrm{Zn}$ deficiency include: growth retardation, reduced appetite, and immunodeficiency $^{(14)}$; the suppression of cytotoxic $\mathrm{T}$ cell activity ${ }^{(15)}$; a reduction in the number of $\mathrm{B}$ cells and their precursors ${ }^{(16)}$; alteration of cytokine secretion ${ }^{(17-20)}$. Most $\mathrm{Zn}$ research has focused on systemic immunity; the effect of $\mathrm{Zn}$ deficiency on the gut-associated lymphoid tissue is unclear. Villous atrophy, oedema, mucosal ulceration, necrosis and inflammation have all been observed in the small intestine of $\mathrm{Zn}$-deficient

\footnotetext{
Abbreviations: CEL, cellulose; DR, diet restricted; DR-CEL, diet-restricted group fed Zn normal control diet containing cellulose; DR-PRE, diet-restricted group fed $\mathrm{Zn}$ normal control diet containing prebiotic inulin; FOS, fructo-oligosaccharide; IFN, interferon; MLN, mesenteric lymph nodes; PP, Peyer's patches; PRE, prebiotic; TCR, T cell receptor; Th, T helper cells; ZD, Zn deficient; ZD-CEL, Zn-deficient diet containing cellulose; ZD-PRE, Zn-deficient diet containing prebiotic inulin; ZN, Zn normal; ZN-CEL, Zn normal control diet containing cellulose; ZN-PRE, Zn normal control diet containing prebiotic inulin.

* Corresponding author: Dr C. G. Taylor, fax +1 204474 7593, email ctaylor@cc.umanitoba.ca
} 
rat models ${ }^{(21,22)}$. Furthermore, Zn may play a role in intestinal permeability as demonstrated by the positive effects of $\mathrm{Zn}$ supplementation on gut permeability in rats with acute colitis $^{(23)}$ and patients with Crohn's disease ${ }^{(24)}$. Since Zn deficiency has been shown to damage the intestinal tract, perhaps $\mathrm{Zn}$ deficiency may also increase intestinal permeability and alter the immune cells in the gut.

To date, no research has explored the effects of prebiotics on gut and immune function using a $\mathrm{Zn}$-deficient model. This research may be important for diseases such as HIV, AIDS and inflammatory bowel diseases, where $\mathrm{Zn}$ deficiency is common and can exacerbate symptoms ${ }^{(25-27)}$. Prebiotics could be advantageous for ameliorating intestinal damage caused by $\mathrm{Zn}$ deficiency based on previous research with probiotics and $\mathrm{Zn}$ deficiency. Mengheri et al. ${ }^{(22)}$ found that the probiotic Bifidobacterium animalis reduced intestinal damage in $\mathrm{Zn-deficient} \mathrm{rats.} \mathrm{Unlike} \mathrm{prebiotics,} \mathrm{probiotics} \mathrm{are} \mathrm{live}$ bacteria that provide health benefits when consumed. Since prebiotics have been shown to increase bifidobacteria in the colon $^{(28)}$, these findings suggest that prebiotics could indirectly protect the intestine against damage caused by $\mathrm{Zn}$ deficiency. Prebiotics may improve both gut and cell-mediated immune function; therefore, we hypothesised that inulin might be beneficial during $\mathrm{Zn}$ deficiency. Thus, the objective of the present research was to determine if inulin alters the number and proportion of immune cells in the spleen, mesenteric lymph nodes (MLN) and Peyer's patches (PP), and ex vivo cytokine secretion as well as intestinal permeability, an indicator of gut barrier function, in growing female rats. An additional objective was to determine if inulin modulates these immune parameters and $\mathrm{Zn}$ status in $\mathrm{Zn}$-adequate $v$. Zn-deficient states.

\section{Materials and methods}

\section{Animals and diets}

Sixty female Sprague-Dawley rats, aged 3 weeks (Charles River Laboratories, St Constant, QC, Canada), weighing about $50-70 \mathrm{~g}$ were acclimatised for $7 \mathrm{~d}$ and then randomly assigned to a $\mathrm{Zn}$ normal (ZN) control diet (30 mg Zn/kg diet, $5 \%$ cellulose) supplemented with either cellulose (CEL; $5 \%$ cellulose; $n$ 30) or inulin (PRE; $5 \%$ inulin, Beneo ${ }^{\mathrm{TM}} \mathrm{HP} ; n$ 30) for 4 weeks. Beneo ${ }^{\mathrm{TM}} \mathrm{HP}$ is a long-chain inulin with an average degree of polymerisation $>23$, and was provided by the Orafti Group (Tienen, Belgium). For an additional 4 weeks, ten rats remained in their original groups (ZN-CEL, $n$ 10; ZN-PRE, $n$ 10). The remaining forty rats were fed a $\mathrm{Zn}$-deficient diet (ZD; $1 \mathrm{mg} \mathrm{Zn}$ per $\mathrm{kg}$ diet) supplemented with cellulose (ZD-CEL; $n$ 10) or inulin (ZD-PRE; $n$ 10) or fed the Zn normal cellulose diet in restricted amounts (DR-CEL; $n$ 10) or $\mathrm{Zn}$ normal inulin diet in restricted amounts (DR-PRE; $n$ 10). These latter two groups were designated as dietrestricted (DR) groups. The DR rats were individually pairfed to the $\mathrm{ZD}$ rats, and all other groups were provided diet ad libitum. A consequence of $\mathrm{Zn}$ deficiency is a reduction in feed intake and growth, thus a DR group was required to differentiate the effects of malnutrition $v$. $\mathrm{Zn}$ deficiency per se. The 4-week Zn deficiency period was based on a preliminary study which demonstrated that serum and femur $\mathrm{Zn}$ concentrations were reduced by 76 and $30 \%$, respectively, in male Sprague-Dawley rats, aged 9 weeks, after consuming a $1 \mathrm{mg} \mathrm{Zn/kg} \mathrm{diet} \mathrm{for} 3$ weeks (NR Ryz and CG Taylor, unpublished results). Female rats were chosen for the present study because $\mathrm{Zn}$ deficiency is more prevalent in the female population $^{(29)}$ and there is a lack of experimental $\mathrm{Zn}$ research using females as the animal model. The diet formulations, based on the AIN-93G diet, are shown in Table 1. The PRE diet $(5 \%$ inulin $+5 \%$ cellulose) was designed to have a sufficient amount of prebiotic to affect immune responses while minimising gastrointestinal side effects ${ }^{(6,30)}$ and to include a source of insoluble fibre for faecal bulking. The rats were maintained in an environment of controlled temperature $\left(21-23^{\circ} \mathrm{C}\right)$, humidity $(55 \%)$ and light cycle $(14 \mathrm{~h}$ light $-10 \mathrm{~h}$ dark). Feed intake was determined daily and body weights were determined weekly. The protocol for animal care procedures received ethics approval from the University of Manitoba Protocol Management and Review Committee.

Table 1. Diet formulations ${ }^{\star}$

\begin{tabular}{lcccc}
\hline Ingredient (g/kg diet) & CEL & ZD-CEL & PRE & ZD-PRE \\
\hline Inulin & 0 & 0 & 50 & 50 \\
Cellulose & 100 & 100 & 50 & 50 \\
Maize starch & $312 \cdot 59$ & $322 \cdot 59$ & $312 \cdot 59$ & $322 \cdot 59$ \\
Maltodextrin & 132 & 132 & 132 & 132 \\
Sucrose & 100 & 100 & 100 & 100 \\
Egg white & $212 \cdot 5$ & $212 \cdot 5$ & $212 \cdot 5$ & $212 \cdot 5$ \\
Biotin mix† & 10 & 10 & 10 & 10 \\
Mineral mix (AIN-93M-MX, Zn-free) & 35 & 35 & 35 & 35 \\
Zn premixł & 10 & 0 & 10 & 0 \\
Vitamin mix (AIN-93-VX) & 10 & 10 & 10 & 10 \\
Potassium phosphate§ & $5 \cdot 4$ & $5 \cdot 4$ & $5 \cdot 4$ & $5 \cdot 4$ \\
Choline & $2 \cdot 5$ & $2 \cdot 5$ & $2 \cdot 5$ & $2 \cdot 5$ \\
Tert-butylhydroquinone & $0 \cdot 014$ & $0 \cdot 014$ & 0.014 & 0.014 \\
Soyabean oil & 70 & 70 & 70 & 70 \\
\hline
\end{tabular}

CEL, cellulose; ZD-CEL, Zn-deficient cellulose; PRE, prebiotic inulin; ZD-PRE, Zn-deficient prebiotic inulin.

${ }^{*}$ All ingredients were from Harlan Teklad (Madison, WI, USA) except potassium phosphate (Fisher Scientific, Mississauga, ON Canada), tert-butylhydroquinone (Aldrich Chemical Company Inc., Milwaukee, WI, USA) and inulin (Orafti Group, Tienen, Belgium). †Biotin mix was $200 \mathrm{mg}$ biotin $/ \mathrm{kg}$ cerelose.

$\ddagger Z n$ premix was $5.775 \mathrm{~g}$ zinc carbonate per $\mathrm{kg}$ cerelose.

§ Additional potassium phosphate was added to make the AIN-93M-MX Zn-free mineral mix equivalent to the AIN-93G-MX. 


\section{Intestinal permeability}

Animals were tested for intestinal permeability using sucrose, lactulose and mannitol probes as previously described ${ }^{(31,32)}$. Elevated concentrations of these intact probes in the urine represent increased permeability in the stomach (sucrose) and small intestine (lactulose:mannitol ratio) ${ }^{(32)}$. At $5 \mathrm{~d}$ before the end of the study, rats were fasted (no food or water) for $4 \mathrm{~h}$, then given a $2 \mathrm{ml}$ solution containing $1 \mathrm{~g}$ sucrose, $120 \mathrm{mg}$ lactulose and $80 \mathrm{mg}$ mannitol by oral administration. Animals were placed in individual metabolism cages for $2 \mathrm{~h}$ with no food or water, and then allowed free access to water for the next $22 \mathrm{~h}$. During this time, urine was collected into plastic tubes containing $10 \%$ thymol as an antibacterial agent and $100 \mu \mathrm{l}$ mineral oil to prevent evaporation. The HPLC methods to determine sucrose, lactulose and mannitol have been previously reported ${ }^{(31)}$.

\section{Tissue collection}

Rats were euthanised by $\mathrm{CO}_{2}$ asphyxiation and decapitation. Trunk blood was collected and stored on ice until centrifuged to obtain serum and stored at $-80^{\circ} \mathrm{C}$. The spleen and MLN were removed aseptically, weighed and processed as previously described ${ }^{(33)}$. The small intestine was flushed with $30 \mathrm{ml}$ cold, sterile Hanks' balanced salt solution with $4 \mathrm{~mm}-$ dithiothreitol, weighed and measured, and PP were removed and immediately processed as previously described ${ }^{(34)}$. To determine total viable cell numbers per tissue, cells were counted using a haemocytometer and trypan blue to distinguish viable from non-viable cells.

\section{Fluorescence staining of lymphocyte subpopulations}

Single-cell suspensions $\left(1 \times 10^{6}\right.$ mononuclear cells/tube $)$ from spleen, MLN and PP were incubated with monoclonal antibodies (obtained, unless stated otherwise, from BD Pharminigen, Mississauga, ON, Canada) for T cell receptor (TCR)- $\alpha \beta$ (R-phycoerythrin label, R73 clone), TCR $\gamma \delta$ (fluorescein isothiocyanate label, V65 clone), CD4 (allophycocyanin label, OX-35 clone), CD8a (peridinin-chlorophyll-protein complex label, OX-8 clone), CD45RA (phycoerythrin-Cy5 label, OX33 clone, which recognises a cell-surface glycoprotein expressed by mature B-cells in the rat) and OX62 (R-phycoerythrin label, MRC OX-62 clone; Serotec, MorphoSyS, Raleigh, NC, USA). OX62 recognises an integrin expressed on both dendritic cells and $\gamma \delta \mathrm{T}$ cells in the rat ${ }^{(35)}$; thus, in the present study, dendritic cells were defined as $\mathrm{OX} 62^{+-}$ $\operatorname{TCR} \gamma \delta^{-}$. The sample combinations for dual-laser analysis were tube $1, \mathrm{TCR} \alpha \beta, \mathrm{TCR} \gamma \delta, \mathrm{CD} 4$ and $\mathrm{CD} 8$ or their respective isotype controls, and tube 2, CD45RA, OX-62 and TCR $\gamma \delta$ or their respective isotype controls. Flow cytometry analysis was performed on a BD FACSCalibur cytometer (BD Biosciences, San Jose, CA, USA) using the BD FACStation data management system software provided with the instrument. Fluorochrome-isotype matched controls were prepared to assess autofluorescence and non-specific binding, and singlecolour samples were employed to adjust colour compensation. Phenotype results were expressed as both proportion and as total number of cells per total tissue collected (calculated by multiplying the percentage for each phenotype by cell counts obtained using the haemocytometer).

\section{Cytokines}

Single-cell suspensions $\left(1 \times 10^{6}\right.$ mononuclear cells/tube $)$ from spleen and MLN were stimulated with $100 \mu$ l concanavalin A $(2.5 \mu \mathrm{g} / \mathrm{ml}$; MP Biomedicals, Solon, OH, USA) for $48 \mathrm{~h}$ at $37^{\circ} \mathrm{C}, 5 \% \mathrm{CO}_{2}$ and $95 \%$ humidity. Concentrations of IL-2, IFN- $\gamma$ and IL-10 in the supernatant fractions were measured by a rat LINCOplex kit (Linco Research Inc., St Charles, MO, USA) following the manufacturer's instructions and analysed with Luminex technology (Lincoplex 200; Luminex Corporation, Austin, TX, USA). Samples were analysed in duplicate and agreement was $\geq 80 \%$.

\section{IgG1 and $\operatorname{IgG} 2 a$}

A sandwich ELISA method was used to measure IgG1 and $\operatorname{IgG} 2 \mathrm{a}$ in the serum. All antibodies and buffers were obtained from BD Pharminigen, Mississauga, Canada unless otherwise noted. Maxisorb ninety-six-well microtiter plates (NUNC, Roskilde, Denmark) were coated with $100 \mu$ l of appropriate coating antibody (mouse anti-rat IgG1 or IgG2a monoclonal antibody diluted 0.20 or $0.50 \mu \mathrm{g} / \mathrm{ml}$, respectively, in PBS) and incubated for $1 \mathrm{~h}$ at room temperature on a shaker. After incubating with $200 \mu \mathrm{l}$ of blocking buffer (PBS containing $1 \%$ (w/v) bovine serum albumin) for $30 \mathrm{~min}$ and washing once (PBS, containing $0.05 \%$ (v/v) Tween 20), $100 \mu \mathrm{l}$ of blanks (blocking buffer), standards (rat reference serum diluted over a range of about 2-1000 ng/ml; Bethyl Laboratories, Montgomery, TX, USA) and samples (diluted 40000 times with blocking buffer) were added and incubated for $1 \mathrm{~h}$ at room temperature on a shaker. After washing three times, $100 \mu \mathrm{l}$ of appropriate detection antibody (biotin-conjugated mouse anti-rat IgG1 or IgG2a monoclonal antibody diluted 0.20 or $0.50 \mu \mathrm{g} / \mathrm{ml}$, respectively, in blocking buffer) was added and incubated for $1 \mathrm{~h}$ at room temperature on a shaker. Plates were washed six times and avidin-horseradish peroxidase conjugate diluted 1:1000 in blocking buffer was added and incubated for $30 \mathrm{~min}$ at room temperature on a shaker. Plates were washed six times, and $100 \mu \mathrm{l}$ tetramethylbenzidine substrate was added, incubated for $20 \mathrm{~min}$ at room temperature on a shaker, followed by the addition of $1.0 \mathrm{M}$-phosphoric acid $(50 \mu \mathrm{l})$ to stop the reaction. Absorbance was read at $450-570 \mathrm{~nm}$ using a microplate reader (SpectraMax 340; Molecular Devices Corp., Sunnyville, CA, USA) and analysed with a 4-parametric logistic curve fit using SOFTmax PRO Software (version 1.2.0; Molecular Devices Corp.). Samples were analysed in triplicate and agreement was $\geq 85 \%$.

\section{Mineral analysis}

Right femurs were excised and thoroughly cleaned of soft tissue. Whole femurs and diet samples were wet-ashed using trace element-grade nitric acid $^{(36)}$ in disposable DigiPrep tubes (SCP Science, Baie d'Urfé, QC, Canada) over 6-7 h at $85^{\circ} \mathrm{C}$ in a DigiPrep HP heater (SCP Science). Acid digests and serum were diluted appropriately with double-deionised water before the analysis of $\mathrm{Zn}$ by atomic absorption spectrometry (Varian Canada, Georgetown, ON, Canada). 


\section{Statistical methods}

Data were analysed by two-way ANOVA (SAS, version 9.1; SAS Institute, Cary, NC, USA) for main effects: fibre (PRE $v$. CEL), diet (ZN, ZD or DR) and fibre $\times$ diet interaction, while feed efficiency was analysed using two-way ANOVA with repeated measures. A significant main effect for fibre determined that pooled means for fibre (CEL $(n$ 30) represents ZN-CEL, ZD-CEL and DR-CEL; PRE (n 30) represents ZNPRE, ZD-PRE and DR-PRE) were significantly different. When main effects for diet were significant, Duncan's multiple-range test was used to determine significant differences among pooled means for diet $(\mathrm{ZN}(n$ 20) represents ZN-CEL and ZN-PRE; ZD ( $n$ 20) represents ZD-CEL and ZD-PRE; DR ( $n$ 20) represents DR-CEL and DR-PRE). When the fibre $\times$ diet interaction was significant, contrast statements were used to determine differences among the six study groups. When necessary, data were normalised by $\log$ transformation but non-transformed means are reported. The level of significance was set at $P<0 \cdot 05$. All data are reported as mean values with their standard errors.

\section{Results}

In the case of no significant interaction (i.e. the effect of fibre (CEL or PRE) was similar regardless of diet (ZN, ZD or DR)), the results are presented for the main effect of fibre and the main effect of diet.

\section{Zinc status and lymphoid organs}

After 8 weeks, the total feed intake of PRE rats was about $7 \%$ lower compared with CEL rats, but there was no difference in final body weight (Table 2) or feed efficiency (Fig. 1 (A)) throughout the study. ZD and DR rats consumed $6 \%$ less total feed and had a $10 \%$ lower final body weight compared with $\mathrm{ZN}$ rats. There was no difference in total feed intake or final body weight between $\mathrm{ZD}$ and $\mathrm{DR}$ rats; however, the feed efficiency of DR rats was higher than $\mathrm{ZD}$ rats at week
6 and week 7 (Fig. 1 (B)). There was no difference in serum $\mathrm{Zn}$ or femur $\mathrm{Zn}$ between CEL and PRE rats. In ZD rats, serum $\mathrm{Zn}$ and femur $\mathrm{Zn}$ were reduced by $85 \%$ and about $30 \%$, respectively, compared with both $\mathrm{ZN}$ and DR rats. There was a significant fibre $\times$ diet interaction such that femur $\mathrm{Zn}$ concentrations in DR-PRE rats were $21 \%$ higher than DR-CEL rats (Fig. 2) but there was no difference between ZN-CEL and ZN-PRE or between ZD-CEL and $\mathrm{ZD}-\mathrm{PRE}$ rats. There was no difference in the $\mathrm{Zn}$ content of the ZN-CEL compared with the ZN-PRE diet (35.3 (SEM 2.3 ) and 34.3 (SEM 1.0) $\mathrm{mg} \mathrm{Zn} / \mathrm{kg}$ diet, respectively; $P<0.05)$ or the ZD-CEL compared with the ZD-PRE diet $(1.17$ (SEM 0.02) and 1.12 (SEM 0.29) $\mathrm{mg} \mathrm{Zn/kg} \mathrm{diet,} \mathrm{respect-}$ ively; $P<0.05$ ). There was no difference in spleen weight among ZN, ZD or DR animals. However, when adjusted for body weight, the spleen of $\mathrm{ZD}$ and DR rats weighed $10 \%$ more than those of $\mathrm{ZN}$ rats. The small intestine weight and length of PRE rats were about $5 \%$ greater than those of CEL rats.

\section{Intestinal permeability}

There was no difference in sucrose permeability or the lactulose:mannitol ratio between PRE and CEL or among ZN, ZD or DR animals (Table 3).

\section{Immune cell phenotyping}

Spleen. Total cell numbers in the spleen were $17 \%$ lower in PRE compared with CEL rats (Table 4). PRE rats had a $4 \%$ higher proportion of $\mathrm{TCR} \alpha \beta^{+} \mathrm{CD} 4^{+}$cells in the spleen compared with CEL rats (74.0 (SEM 0.8) and 71.3 (SEM 0.9) \% of cells, respectively; $P=0.02$ ). PRE rats had $24 \%$ fewer $\mathrm{TCR} \alpha \beta^{+} \mathrm{CD}^{+}$cell numbers compared with CEL rats and a $10 \%$ lower proportion of $\mathrm{TCR} \alpha \beta^{+} \mathrm{CD} 8^{+}$cells (PRE: 22.4 (SEM 0.8) \% of cells, CEL: 25.0 (SEM 0.8) \% of cells; $P=0.02)$. TCR $\gamma \delta^{+}$cell numbers were $22 \%$ lower in the spleen of PRE rats compared with those of CEL rats. ZD and DR rats had a $7 \%$ lower proportion of $\mathrm{CD}_{4} 5 \mathrm{RA}^{+}$cells

Table 2. Body weight, feed intake, serum zinc and lymphoid organs* (Mean values with their standard errors)

\begin{tabular}{|c|c|c|c|c|c|c|c|c|c|c|c|c|}
\hline & \multicolumn{5}{|c|}{ Fibre effect $(n 60)$} & \multicolumn{7}{|c|}{ Diet effect $(n 60)$} \\
\hline & \multicolumn{2}{|c|}{ CEL $(n 30) \dagger$} & \multicolumn{2}{|c|}{ PRE (n 30)† } & \multirow[b]{2}{*}{$P$} & \multicolumn{2}{|c|}{ ZN $(n 20) \ddagger$} & \multicolumn{2}{|c|}{ ZD (n 20)‡ } & \multicolumn{2}{|c|}{$\mathrm{DR}(n 20) \ddagger$} & \multirow[b]{2}{*}{$P$} \\
\hline & Mean & SEM & Mean & SEM & & Mean & SEM & Mean & SEM & Mean & SEM & \\
\hline Body weight (g) & 254 & 4 & 250 & 6 & NS & $271^{a}$ & 5 & $242^{b}$ & 5 & $244^{b}$ & 6 & 0.0006 \\
\hline Total feed intake (g) & 907 & 13 & 846 & 14 & 0.0006 & $924^{\mathrm{a}}$ & 18 & $872^{\mathrm{b}}$ & 16 & $834^{\mathrm{b}}$ & 13 & 0.0003 \\
\hline Serum Zn $(\mu \mathrm{mol} / \mathrm{l})$ & 14.6 & $1 \cdot 7$ & 14.9 & 1.6 & NS & $20 \cdot 7^{a}$ & 0.9 & $3 \cdot 1^{b}$ & 0.5 & $20 \cdot 6^{\mathrm{a}}$ & 0.8 & $<0.0001$ \\
\hline Spleen $(\mathrm{mg})$ & 545 & 15 & 551 & 13 & NS & 551 & 14 & 540 & 20 & 552 & 17 & NS \\
\hline Spleen ( $\mathrm{g} / \mathrm{g}$ body weight) & 0.22 & 0.01 & 0.22 & 0.01 & NS & $0.20^{\mathrm{b}}$ & 0.01 & $0.22^{\mathrm{a}}$ & 0.01 & $0.23^{\mathrm{a}}$ & 0.01 & 0.02 \\
\hline $\begin{array}{l}\text { Small intestine }(\mathrm{g} / \mathrm{g} \text { body } \\
\text { weight } \times 100)\end{array}$ & $20 \cdot 6$ & 0.3 & 21.9 & 0.4 & 0.01 & $21 \cdot 3$ & 0.5 & $21 \cdot 8$ & 0.4 & $20 \cdot 5$ & 0.5 & NS \\
\hline Small intestine $(\mathrm{cm})$ & 104 & 1 & 108 & 1 & 0.003 & 104 & 1 & 105 & 1 & 108 & 1 & NS \\
\hline
\end{tabular}

CEL, cellulose; PRE, prebiotic inulin; ZN, Zn normal control diet; ZD, Zn-deficient diet; DR, Zn normal control diet provided in restricted amounts.

$a, b$ For the diet effect, mean values within a row with unlike superscript letters were significantly different $(P \leq 0.05)$.

${ }^{*}$ As there were no interactions between fibre (CEL or PRE) and diet (ZN, ZD, DR), but there were significant main effects of fibre and significant main effects of diet, data were pooled to show pooled means for the main effects only.

† CEL ( $n 30)$ represents ZN-CEL, ZD-CEL and DR-CEL groups and PRE ( $n 30)$ represents ZN-PRE, ZD-PRE and DR-PRE groups; for details, see Animals and diets

$\ddagger Z N(n 20)$ represents ZN-CEL and ZN-PRE groups, ZD ( $n$ 20) represents ZD-CEL and ZD-PRE groups and DR ( $n$ 20) represents DR-CEL and DR-PRE groups; for details,

see Animals and diets. 

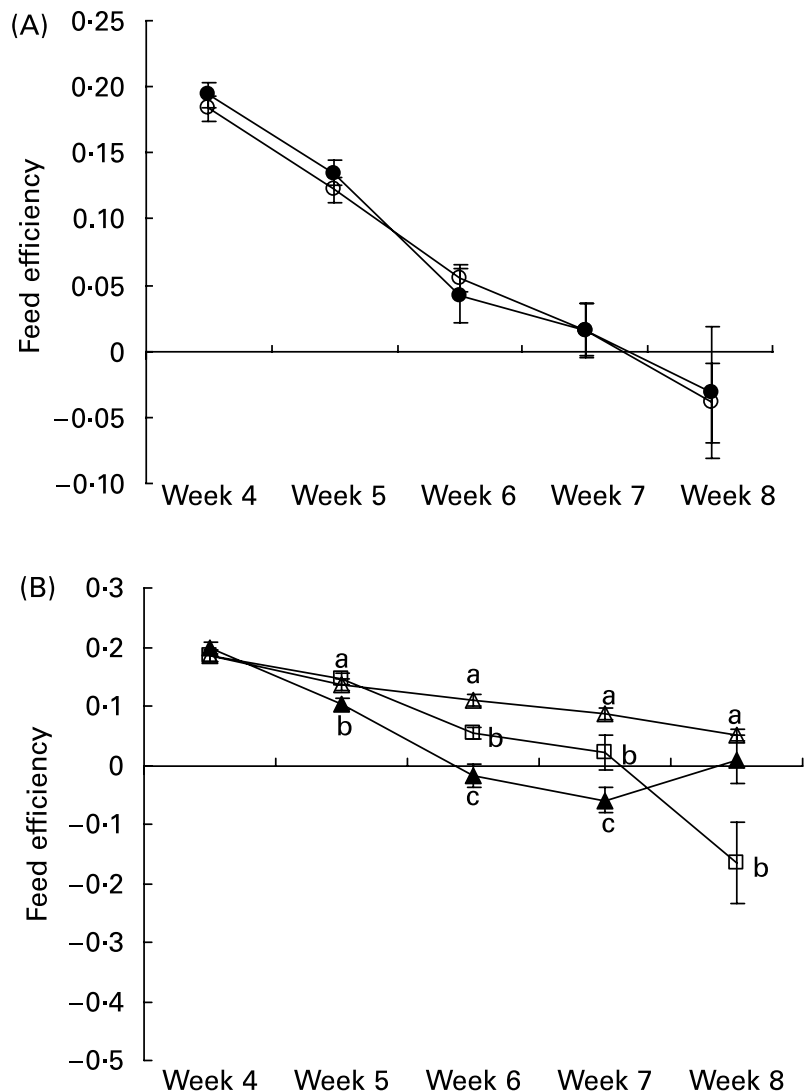

Fig. 1. Feed efficiency over time (calculated as $\mathrm{g}$ weight gain per week/g feed intake per week). (A) Fibre effect, (B) diet effect. (O), Cellulose; (๑), prebiotic inulin; $(\triangle)$, Zn normal control diet; $(\boldsymbol{\Lambda}), \mathrm{Zn}$-deficient diet; ( $\square), \mathrm{Zn}$ normal control diet provided in restricted amounts. Values are means, with standard errors represented by vertical bars. For details of groups, see Table 2. Data were analysed by two-way ANOVA with repeated measures. There was a significant main effect for diet $(P<0.0001)$. There were no significant main effects for fibre or fibre $\times$ diet interaction. ${ }^{a, b, c}$ Mean values with unlike letters were significantly different $(P \leq 0.05)$.

in the spleen compared with ZN rats (54.5 (SEM 1.4), 54.3 (SEM 1.1) and 58.4 (SEM 0.9) \% of cells, respectively; $P=0.02)$. There were no differences in TCR $\alpha \beta^{+}, \operatorname{TCR} \gamma \delta^{+-}$ $\mathrm{CD} 4^{+}, \mathrm{TCR} \gamma \delta^{+} \mathrm{CD} 8^{+}$, or $\mathrm{OX} 62^{+} \mathrm{TCR} \gamma \delta^{-}$cell numbers or proportions of these cells in the spleen between PRE and CEL or among $\mathrm{ZN}, \mathrm{ZD}$ or DR rats.

Mesenteric lymph nodes. Total cell numbers in the MLN were $16 \%$ lower in PRE compared with CEL rats, and numbers in $\mathrm{ZD}$ rats were 29 and $59 \%$ lower compared with $\mathrm{ZN}$

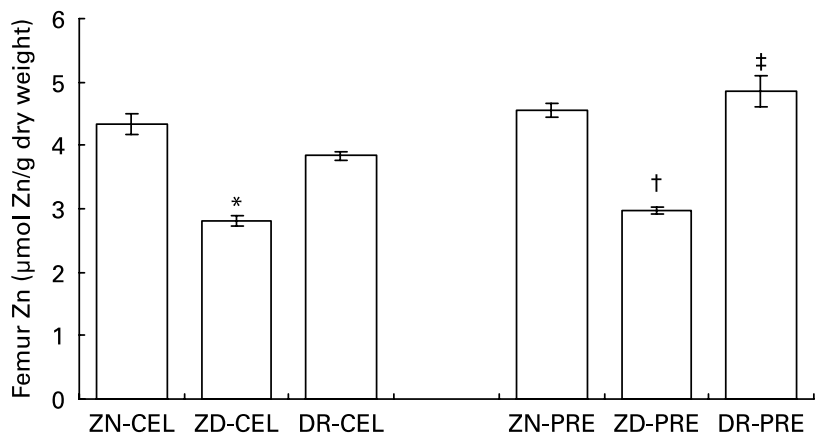

Fig. 2. Femur Zn concentration. ZN-CEL, Zn normal cellulose; ZD-CEL, Zndeficient cellulose; DR-CEL, diet restricted cellulose; ZN-PRE, Zn normal prebiotic inulin; ZD-PRE, Zn-deficient prebiotic inulin; DR-PRE, diet restricted prebiotic inulin. Values are means, with standard errors represented by vertical bars. Significant main effects were fibre $(P=0.0001)$, diet $(P<0.0001)$ and fibre $\times$ diet interaction $(P=0.0042)$. Since there was a significant interaction by two-way ANOVA, individual study groups are shown. *Mean value was significantly different from that of the ZN-CEL and DR-CEL groups $(P \leq 0.05)$. † Mean value was significantly different from that of the ZN-PRE and DR-PRE groups $(P \leq 0 \cdot 05)$. $¥$ Mean value was significantly different from that of the DR-CEL group $(P \leq 0.05)$.

and DR rats, respectively (Table 4). TCR $\alpha \beta^{+} \mathrm{CD} 8^{+}$cell numbers were $15 \%$ lower in the MLN of PRE rats compared with CEL rats. PRE rats had $22 \%$ fewer $\mathrm{CD}_{45 \mathrm{RA}}{ }^{+}$cell numbers compared with CEL rats and an $8 \%$ lower proportion of CD45RA $^{+}$cells (PRE: 32.9 (SEM 0.9) \% of cells; CEL: 35.8 (SEM 1.0) $\%$ of cells; $P=0 \cdot 03$ ). TCR $\alpha \beta^{+}, \mathrm{TCR} \alpha \beta^{+} \mathrm{CD} 4^{+}$ and $\mathrm{TCR} \gamma \delta^{+}$cell numbers in ZD rats were about $30 \%$ and about $50 \%$ lower compared with $\mathrm{ZN}$ and DR rats, respectively. TCR $\alpha \beta^{+} \mathrm{CD} 8^{+}$and $\mathrm{TCR} \gamma \delta^{+} \mathrm{CD} 8^{+}$cell numbers in $\mathrm{ZD}$ rats were about $50 \%$ lower compared with both $\mathrm{ZN}$ and DR rats. DR rats had about $36 \%$ higher $\mathrm{CD}_{45 \mathrm{RA}^{+}}$cell numbers compared with $\mathrm{ZN}$ and $\mathrm{ZD}$ rats. There were no differences in $\mathrm{TCR} \gamma \delta^{+} \mathrm{CD} 4^{+}$or $\mathrm{OX} 62^{+} \mathrm{TCR} \gamma \delta^{-}$cell numbers or proportions of these cells in the MLN between PRE and CEL rats or among $\mathrm{ZN}, \mathrm{ZD}$ or $\mathrm{DR}$ rats.

Peyer's patches. Total cell numbers in the PP had a significant fibre $\times$ diet interaction $(P=0 \cdot 01)$; however, contrast statements did not reveal any significant differences among study groups (Table 5). There was another significant fibre $\times$ diet interaction in the PP, such that $\mathrm{TCR} \gamma \delta^{+}$cell numbers were $53 \%$ higher in ZD-PRE rats compared with ZD-CEL rats. The proportion of $\mathrm{TCR} \alpha \beta^{+} \mathrm{CD} 8$ cells was $10 \%$ lower in PP of PRE rats compared with CEL rats (14.1 (SEM 0.5) and 16.2 (SEM 0.6 ) $\%$ of cells, respectively; $P=0.005$ ). PRE rats had a $50 \%$ higher $\mathrm{OX} 62^{+} \mathrm{TCR} \gamma \delta^{-}$cell number

Table 3. Intestinal permeability*

(Mean values with their standard errors)

\begin{tabular}{|c|c|c|c|c|c|c|c|c|c|c|}
\hline & \multicolumn{4}{|c|}{ Fibre effect } & \multicolumn{6}{|c|}{ Diet effect } \\
\hline & \multicolumn{2}{|c|}{ CEL } & \multicolumn{2}{|c|}{ PRE } & \multicolumn{2}{|c|}{$Z N$} & \multicolumn{2}{|c|}{ ZD } & \multicolumn{2}{|c|}{ DR } \\
\hline & Mean & SEM & Mean & SEM & Mean & SEM & Mean & SEM & Mean & SEM \\
\hline Sucrose & 0.007 & 0.001 & 0.007 & 0.001 & 0.007 & 0.001 & 0.006 & 0.001 & 0.008 & 0.001 \\
\hline Lactulose:mannitol & 0.31 & 0.01 & 0.33 & 0.02 & 0.34 & 0.02 & 0.30 & 0.02 & 0.32 & 0.02 \\
\hline
\end{tabular}

CEL, cellulose; PRE, prebiotic inulin; ZN, Zn normal control diet; ZD, Zn-deficient diet; DR, Zn normal control diet provided in restricted amounts.

${ }^{\star}$ Results are expressed as fractional excretion (fraction of the orally administered dose recovered in the urine sample) or the ratio of fractional excretion (lactulose:mannitol). Data were analysed by two-way ANOVA, but there were no significant main effects. 
Table 4. Immune cells in the spleen, mesenteric lymph nodes and Peyer's patches* (Mean values with their standard errors)

\begin{tabular}{|c|c|c|c|c|c|c|c|c|c|c|c|c|}
\hline \multirow[b]{3}{*}{ Cell numbers $\left(\times 10^{4}\right)$} & \multicolumn{5}{|c|}{ Fibre effect } & \multicolumn{7}{|c|}{ Diet effect } \\
\hline & \multicolumn{2}{|c|}{ CEL } & \multicolumn{2}{|c|}{ PRE } & \multirow[b]{2}{*}{$P$} & \multicolumn{2}{|c|}{ ZN } & \multicolumn{2}{|c|}{ ZD } & \multicolumn{2}{|c|}{ DR } & \multirow[b]{2}{*}{$P$} \\
\hline & Mean & SEM & Mean & SEM & & Mean & SEM & Mean & SEM & Mean & SEM & \\
\hline \multicolumn{13}{|l|}{ Spleen } \\
\hline Total cells & 1206 & 68 & 1006 & 62 & 0.03 & 1197 & 81 & 1039 & 97 & 1082 & 66 & NS \\
\hline TCR $\alpha \beta^{+} \mathrm{CD}^{+}$cells & 98 & 7 & 75 & 5 & 0.01 & 95 & 9 & 83 & 9 & 81 & 6 & NS \\
\hline TCR $\gamma \delta^{+}$cells & $18 \cdot 9$ & 1.4 & 14.7 & 1.5 & 0.05 & $18 \cdot 8$ & $1 \cdot 7$ & $15 \cdot 4$ & $1 \cdot 8$ & $16 \cdot 2$ & $2 \cdot 0$ & NS \\
\hline \multicolumn{13}{|l|}{ Mesenteric lymph nodes } \\
\hline Total cells & 335 & 26 & 282 & 25 & 0.05 & $299^{b}$ & 23 & $213^{c}$ & 18 & $418^{a}$ & 34 & $<0.0001$ \\
\hline TCR $\alpha \beta^{+}$cells & 194 & 15 & 171 & 15 & NS & $181^{\mathrm{b}}$ & 15 & $124^{c}$ & 11 & $244^{a}$ & 19 & $<0.0001$ \\
\hline $\mathrm{TCR} \alpha \beta^{+} \mathrm{CD} 4^{+}$cells & 153 & 12 & 137 & 12 & NS & $142^{\mathrm{b}}$ & 11 & $100^{c}$ & 9 & $195^{\mathrm{a}}$ & 15 & $<0.0001$ \\
\hline $\mathrm{TCR} \alpha \beta^{+} \mathrm{CD}^{+}$cells & 34 & 3 & 29 & 3 & 0.01 & $33^{a}$ & 3 & $20^{\mathrm{b}}$ & 2 & $41^{\mathrm{a}}$ & 4 & $<0.0001$ \\
\hline TCR $\gamma \delta^{+}$cells & $2 \cdot 69$ & 0.33 & $2 \cdot 22$ & 0.3 & NS & $2 \cdot 53^{b}$ & 0.29 & $1.42^{\mathrm{C}}$ & 0.15 & $3.47^{\mathrm{a}}$ & 0.43 & 0.0002 \\
\hline TCR $\gamma \delta^{+} \mathrm{CD}^{+}$cells & 2.44 & 0.31 & 1.98 & 0.27 & NS & $2 \cdot 27^{a}$ & 0.26 & $1.26^{\mathrm{b}}$ & 0.14 & $3 \cdot 17^{a}$ & 0.40 & 0.0001 \\
\hline $\mathrm{CD} 4 \mathrm{RA}^{+}$cells & 121 & 11 & 94 & 8 & 0.02 & $97^{\mathrm{b}}$ & 8 & $79^{\mathrm{b}}$ & 8 & $148^{\mathrm{a}}$ & 14 & 0.0001 \\
\hline \multicolumn{13}{|l|}{ Peyer's patches } \\
\hline TCR $\alpha \beta^{+} \mathrm{CD} 8^{+}$cells & $12 \cdot 9$ & 0.8 & $12 \cdot 0$ & 0.7 & NS & $11 \cdot 3^{b}$ & 0.9 & $11.9^{b}$ & 0.8 & $14 \cdot 5^{\mathrm{a}}$ & 1.0 & 0.04 \\
\hline
\end{tabular}

CEL, cellulose; PRE, prebiotic inulin; ZN, Zn normal control diet; ZD, Zn-deficient diet; DR, Zn normal control diet provided in restricted amounts.

$a, b, c$ For the diet effect, mean values within a row with unlike superscript letters were significantly different $(P \leq 0 \cdot 05)$.

${ }^{*}$ Data are shown for total cells or subpopulations of immune cells when there was a significant main effect of fibre and/or diet. Cell numbers are expressed $\times 10^{4}$. Total cells are per total tissue collected (spleen, mesenteric lymph nodes or Peyer's patches). TCR $\alpha \beta^{+}, \mathrm{TCR}_{\gamma} \delta^{+}$and CD45RA ${ }^{+}$cells are the number of respective cells in each tissue. TCR $\alpha \beta^{+} \mathrm{CD} 4^{+}$and TCR $\alpha \beta^{+} \mathrm{CD} 8^{+}$cells are the number of the respective subsets calculated from the total number of TCR $\alpha \beta^{+}$cells. Similarly, TCR $\delta^{+} \mathrm{CD} 8^{+}$cells are calculated from the total number of TCR $\gamma \delta^{+}$cells.

and a $31 \%$ higher proportion of $\mathrm{OX} 62^{+} \mathrm{TCR} \gamma \delta^{-}$cells in the PP compared with CEL rats (Fig. 3). The proportion of TCR $\alpha \beta^{+}$cells was $15 \%$ higher in DR animals compared with ZN and ZD animals (17.5 (SEM 0.9), 14.9 (SEM 0.6) and $15 \cdot 1$ (SEM 0.9 ) \% of cells, respectively; $P=0.04)$. DR rats had a $10 \%$ higher proportion of $\mathrm{TCR} \alpha \beta^{+} \mathrm{CD}^{+}$cells compared with $\mathrm{ZN}$ and ZD rats (16.6 (SEM 0.7), 14.5 (SEM 0.8 ) and 14.3 (SEM 0.6) \% of cells, respectively; $P=0.02$ ). The proportion of $\mathrm{CD}_{45 \mathrm{RA}^{+}}$cells was $4 \%$ higher in both $\mathrm{ZN}$ and $\mathrm{ZD}$ rats compared with DR rats (77.4 (SEM 1.0), 77.9 (SEM 0.9 ) and 74.6 (SEM 1.0$) \%$ of cells, respectively; $P=0 \cdot 04)$. There were no differences in $\mathrm{TCR} \alpha \beta^{+} \mathrm{CD} 4^{+}$, $\mathrm{TCR} \gamma \delta^{+} \mathrm{CD} 4^{+}$or $\mathrm{TCR} \gamma \delta^{+} \mathrm{CD} 8^{+}$cell numbers or proportion of these cells in the PP between PRE and CEL rats or among ZN, ZD or DR rats (data not shown).

\section{Cytokines}

Concanavalin A-stimulated ex vivo secretion of IL-2, IL-10 and IFN- $\gamma$ in both the spleen and MLN was $40-70 \%$ higher in PRE rats compared with CEL rats (Fig. 4). Neither ZD nor DR had an effect on cytokine secretion in the spleen or MLN.

\section{IgG1 and $\operatorname{IgG} 2 a$}

There was no difference in serum IgG1 or IgG2a between $\mathrm{PRE}$ and CEL rats. There was no difference in serum $\mathrm{IgG1}$ among ZD, ZN or DR animals (Fig. 5 (A)). Serum IgG2a of $\mathrm{ZD}$ rats was about $35 \%$ lower than both $\mathrm{ZN}$ and $\mathrm{DR}$ rats (Fig. 5 (B)).

\section{Discussion}

This is the first study to show that inulin can increase the proportion and number of dendritic cells $\left(\mathrm{OX} 62^{+} \mathrm{TCR} \gamma \delta^{-}\right)$ in the PP. It has previously been shown that the percentage of IL-10 positive dendritic cells is increased in the lamina propria following oral consumption of FOS in patients with moderately active Crohn's disease ${ }^{(7)}$. An increase in the numbers of dendritic cells has been associated with

Table 5. Immune cells in Peyer's patches*

(Mean values with their standard errors)

\begin{tabular}{|c|c|c|c|c|c|c|c|c|c|c|c|c|c|}
\hline \multirow[b]{3}{*}{ Cell numbers $\left(\times 10^{4}\right)$} & \multicolumn{6}{|c|}{ Cellulose } & \multicolumn{6}{|c|}{ Prebiotic } & \multirow[b]{3}{*}{ Main effects $(P)$} \\
\hline & \multicolumn{2}{|c|}{ ZN-CEL } & \multicolumn{2}{|c|}{ ZD-CEL } & \multicolumn{2}{|c|}{ DR-CEL } & \multicolumn{2}{|c|}{ ZN-PRE } & \multicolumn{2}{|c|}{ ZD-PRE } & \multicolumn{2}{|c|}{ DR-PRE } & \\
\hline & Mean & $\overline{\text { SEM }}$ & Mean & $\overline{\text { SEM }}$ & Mean & $\overline{\text { SEM }}$ & Mean & SEM & Mean & $\overline{\text { SEM }}$ & Mean & SEM & \\
\hline Total cells & 71 & 8 & 70 & 6 & 101 & 7 & 86 & 1 & 104 & 8 & 81 & 11 & Fibre $\times$ diet 0.01 \\
\hline TCR $\gamma \delta^{+}$ & 0.21 & 0.03 & 0.18 & 0.03 & 0.33 & 0.05 & 0.30 & 0.05 & $0.38 \dagger$ & 0.04 & 0.29 & 0.06 & $\begin{array}{r}\text { Fibre } 0.03 \\
\text { Fibre } \times \text { diet } 0.05\end{array}$ \\
\hline
\end{tabular}

ZN-CEL, Zn normal cellulose; ZD-CEL, Zn-deficient cellulose; DR-CEL, diet-restricted cellulose; ZN-PRE, Zn normal prebiotic inulin; ZD-PRE, Zn-deficient prebiotic inulin; DR-PRE, diet-restricted prebiotic inulin.

* Since there was a significant interaction by two-way ANOVA, individual groups are shown. Although there was a significant fibre $\times$ diet interaction for total cells, contrast statements did not reveal any significant differences among means for the six study groups. Total cells and TCR $\gamma \delta^{+}$cells are per total tissue collected.

† Mean value was significantly different from that of the ZD-CEL group $(P \leq 0.05)$. 

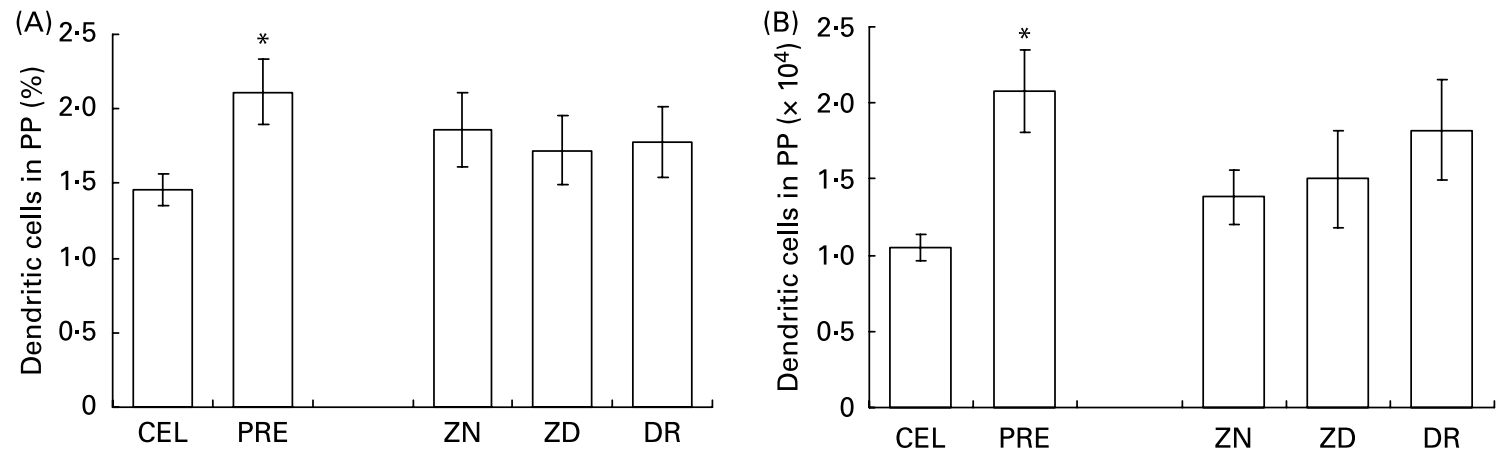

Fig. 3. Dendritic cells in Peyer's patches. (A) Proportion of dendritic cells $\left(\mathrm{OX} 62^{+} \mathrm{TCR} \gamma \delta^{-}\right.$as a percentage of total cells). CEL, cellulose; PRE, prebiotic inulin; ZN, $\mathrm{Zn}$ normal control diet; ZD, Zn-deficient diet; DR, Zn normal control diet provided in restricted amounts. Values are means, with standard errors represented by vertical bars. For details of groups and analysis, see Table 2. ${ }^{*}$ There was a significant main effect of fibre $(P=0.01)$. (B) Dendritic cell numbers $\left(O X 62^{+}{ }^{+}\right.$CR $\gamma \delta$ cells $\left.\times 10^{4}\right)$. ${ }^{*}$ There was a significant main effect of fibre $(P=0.0001)$. There were no significant main effects for diet or for fibre $\times$ diet interaction.
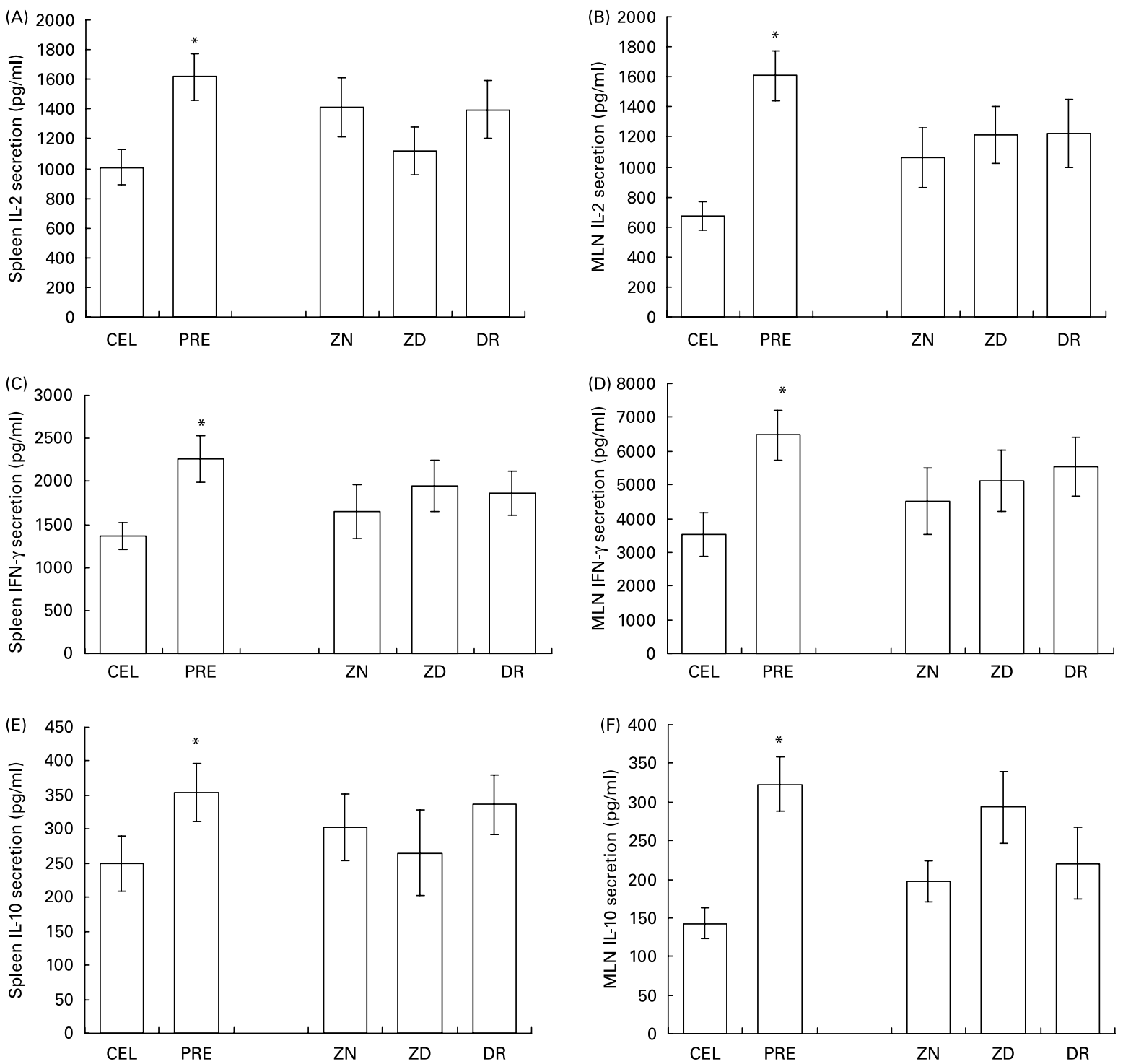

Fig. 4. Ex-vivo cytokine secretion of immune cells from the spleen and mesenteric lymph nodes (MLN). (A) IL-2 secretion from spleen cells, (B) IL-2 secretion from MLN cells, (C) interferon (IFN)- $\gamma$ secretion from spleen cells, (D) IFN- $\gamma$ secretion from MLN cells, (E) IL-10 secretion from spleen cells, (F) IL-10 secretion from MLN cells. CEL, cellulose; PRE, prebiotic inulin; ZN, Zn normal control diet; ZD, Zn-deficient diet; DR, Zn normal control diet provided in restricted amounts. Values are means, with standard errors represented by vertical bars. For details of groups and analysis, see Table 2. * There were significant main effects for fibre: IL-2 from spleen ( $P=0.006)$; IL-2 from MLN $(P<0.0001)$; IFN- $\gamma$ from spleen $(P=0.008)$; IFN- $\gamma$ from MLN $(P=0.005)$; IL-10 from spleen $(P=0.01)$; IL-10 from MLN $(P<0.0001)$. There were no significant main effects for diet or fibre $\times$ diet interaction. 

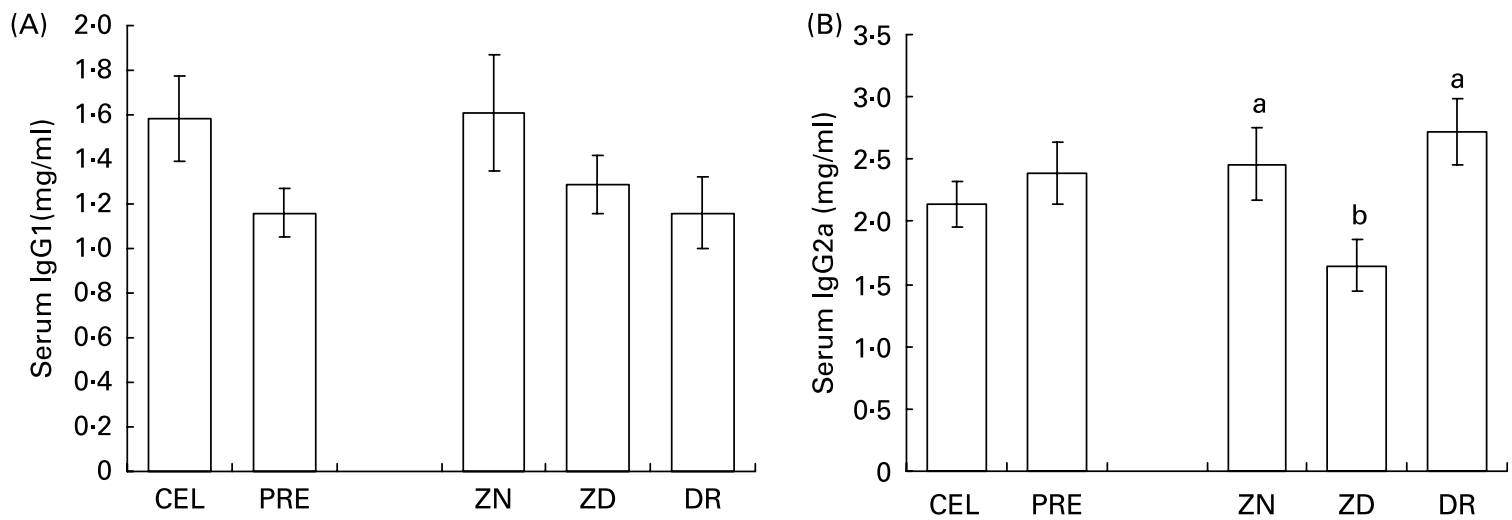

Fig. 5. Serum IgG1 (A) and IgG2a (B) concentrations. CEL, cellulose; PRE, prebiotic inulin; ZN, Zn normal control diet; ZD, Zn-deficient diet; DR, Zn normal control diet provided in restricted amounts. Values are means, with standard errors represented by vertical bars. For details of groups and analysis, see Table 2 . For serum IgG2a there was a significant main effect for diet $(P=0.002)$. ${ }^{a, b}$ Mean values with unlike letters were significantly different $(P \leq 0.05)$. There were no significant main effects for fibre or fibre $\times$ diet interaction.

increased immunological tolerance ${ }^{(37)}$, which is the immune unresponsiveness to dietary antigens and indigenous bacterial antigens $^{(38)}$. Prebiotics may increase dendritic cells indirectly through the modulation of indigenous bacteria. For instance, Smits et al. ${ }^{(39)}$ have demonstrated that the probiotics Lactobacillus reuteri and $L$. casei were able to prime dendritic cells to promote the development of regulatory $\mathrm{T}$ cells, which mediate tolerance by inhibiting the proliferation and cytokine production of effector $\mathrm{T}$ cells. Further research is required to determine if prebiotics can alter the function of dendritic cells.

Most prebiotic studies are 4-6 weeks long ${ }^{(3,5,40)}$, which may not be long enough to affect systemic immunity; however, the present 8 -week study with long-chain inulin (Beneo ${ }^{\mathrm{TM}} \mathrm{HP}$; average degree of polymerisation $>23$ ) was sufficient to alter the proportion and number of immune cells in the spleen and gut. The changes in the proportion of $\mathrm{T}$ and $\mathrm{B}$ cells between CEL and PRE rats were small, but statistically significant. Other studies found no difference in the proportion of $\mathrm{T}$ and $\mathrm{B}$ cells in the spleen or MLN of mice fed $10 \%$ oligofructose or inulin for 6 weeks compared with $10 \%$ cellulose $^{(40)}$, or rats supplemented with a combination of inulin and oligofructose (Synergy1) for 4 weeks ${ }^{(3)}$. Manhart et al. ${ }^{(5)}$ found that both healthy and endotoxaemic female mice supplemented with $10 \%$ FOS for $16 \mathrm{~d}$ had an increased proportion of B cells in PP, while T cells were only increased in the PP of endotoxaemic mice fed the FOS diet.

Interestingly, there was a fibre $\times$ diet interaction in the $\mathrm{PP}$, such that ZD-PRE rats had $53 \%$ higher $\mathrm{TCR} \gamma \delta^{+}$cell numbers compared with ZD-CEL rats, which may indicate a protective function of inulin during $\mathrm{Zn}$ deficiency. To our knowledge, this is the first study to examine the effects of prebiotic and $\mathrm{Zn}$ deficiency on $\mathrm{TCR} \gamma \delta^{+}$cells in the gut. Splenic TCR $\gamma \delta^{+}$cells were unaltered by $\mathrm{Zn}$ deficiency in agreement with Hosea et al. ${ }^{(41)}$. T cells expressing the $\gamma \delta$ TCR are a minor T-cell population in the circulation and lymphoid organs, but they represent a major subset within the epithelia of intestine and skin. The functions of $\gamma \delta \mathrm{T}$ cells are not well understood, but they seem to play a key role in oral tolerance and have anti-inflammatory and immunosuppressive activities ${ }^{(42)}$. In murine models, intestinal $\gamma \delta$ intra-epithelial lymphocytes have been shown to play a protective role in disease conditions associated with tissue damage, such as inflammatory bowel disease ${ }^{(42)}$.

In the present study, PRE rats had greater ex vivo secretion of cytokines (IL-2, IL-10 and IFN- $\gamma$ ) in the spleen and MLN. Prebiotic studies with an experimental period of 4-6 weeks have found that shorter-chain prebiotics, such as FOS, or a combination of long- and short-chain prebiotics (Synergy1) increased ex vivo secretion of IL-10 and IFN- $\gamma$ in the PP, but had fewer effects in the spleen or MLN of rats ${ }^{(3,5,6)}$. In a long-term study, Roller et al. ${ }^{(4)}$ found that rats fed Synergy 1 for 33 weeks had increased ex vivo secretion of IL-10 in both PP and MLN, but no effects in the spleen.

There are three potential mechanisms through which prebiotics may affect the immune system. First, prebiotics stimulate the proliferation of beneficial bacteria, including Bifidobacterium and Lactobacillus ${ }^{(43)}$, which can interact with the host. Cells of the innate immune system, including dendritic cells, express toll-like receptors, which recognise specific pathogen-associated molecular patterns, including bacterial DNA. Toll-like receptor signalling can trigger signal transduction cascades, such as the NF-кB system, resulting in the secretion of cytokines ${ }^{(44)}$. Bifidobacteria and Lactobacillus have also been shown to increase the proportion of $\mathrm{CD}^{+} \mathrm{T}$ cells in the spleen $^{(45)}$ and the gut ${ }^{(46)}$. Second, bacteria in the large intestine can completely degrade prebiotics to yield SCFA, including butyrate, acetate and propionate ${ }^{(47)}$. Butyrate has been shown to increase ex vivo secretion of IL-10, while inhibiting IL-2 and IFN- $\gamma^{(48-50)}$, while acetate and propionate have been shown to increase ex vivo secretion of IFN- $\gamma^{(48)}$. In addition, butyrate has been shown to inhibit $\mathrm{T}$ cell activation and $\mathrm{B}$ cell function ${ }^{(51-54)}$. SCFA also support the epithelial cell mass ${ }^{(55)}$, which may be reflected by the increase in length and weight of the small intestine as observed in the present study and others ${ }^{(56,57)}$. The third mechanism may involve the interaction of prebiotics with carbohydrate receptors on immune cells. For instance, a $\beta$-glucan dectin-1 receptor has been identified on neutrophils, monocytes and macrophages ${ }^{(58,59)}$. It is presently unknown if fructose receptors exist on immune cells ${ }^{(60)}$.

Prebiotics and their metabolites may play a role in increasing intestinal $\mathrm{Zn}$ absorption ${ }^{(61)}$ and potentially improving $\mathrm{Zn}$ status as assessed by femur $\mathrm{Zn}$ concentrations. Interestingly, 
inulin helped to conserve femur $\mathrm{Zn}$ concentrations during diet restriction, when dietary $\mathrm{Zn}$ was available despite reduced energy intake, but not during dietary $\mathrm{Zn}$ deficiency when availability of $\mathrm{Zn}$ was severely limited. However, bone $\mathrm{Zn}$ concentrations were not altered by inulin consumption in healthy ad libitum-fed rats with adequate dietary $\mathrm{Zn}$ intake (present study and Coudray et al. ${ }^{(61)}$ ). Raschka \& Daniel ${ }^{(13)}$ found that femur $\mathrm{Zn}$ was increased by $8 \%$ in male adolescent rats provided with a mixture of short- and long-chain prebiotics for $15 \mathrm{~d}$, suggesting that shorter-chain prebiotics may be effective for increasing $\mathrm{Zn}$ absorption.

$\mathrm{ZD}$ rats had about a $35 \%$ drop in serum IgG2a, which has previously been demonstrated in mice ${ }^{(62)}$. The IgG2a subclass reflects a Th1 immune response and since $\mathrm{Zn}$ deficiency is known to inhibit type 1 responses ${ }^{(63)}$, the present results appear logical. Very little is known about the impact of Zn deficiency and diet restriction on mucosal immunity. Interestingly, diet restriction altered the proportion of immune cells in the PP; DR rats had a $10-15 \%$ higher proportion of $\mathrm{TCR} \alpha \beta^{+}$and $\mathrm{TCR} \alpha \beta^{+} \mathrm{CD}^{+}$cells, and a $4 \%$ lower proportion of CD45RA ${ }^{+}$cells in the PP compared with both ZN and ZD rats. In the MLN, ZD rats had lower T cell numbers $\left(\mathrm{TCR} \alpha \beta^{+}\right.$, $\mathrm{TCR} \alpha \beta^{+} \mathrm{CD}^{+}, \mathrm{TCR} \alpha \beta^{+} \mathrm{CD} 8^{+}, \mathrm{TCR}_{\gamma} \delta^{+}, \mathrm{TCR} \gamma \delta^{+} \mathrm{CD} 8^{+}$) compared with $\mathrm{ZN}$ and $\mathrm{DR}$ rats. However, in the present study, Zn deficiency did not alter immune markers in the spleen. It appears that $\mathrm{Zn}$ deficiency in young adult female rats is not as detrimental to systemic immunity as compared with $\mathrm{Zn}$ deficiency in male weanling rats ${ }^{(64,65)}$, which may be attributed to the degree of $\mathrm{Zn}$ deficiency. For instance, based on experiences in our laboratory with the same $\mathrm{Zn}$-deficient diet and experimental conditions, femur $\mathrm{Zn}$ concentrations were about $70 \%$ lower in weanling male rats ${ }^{(41,66,67)}$ compared with $35 \%$ lower in older female rats (present study), even though serum $\mathrm{Zn}$ was reduced by about $80 \%$ in all studies.

We postulated that prebiotic ingestion may help normalise the gastrointestinal barrier dysfunction in Zn-deficient rats; however, gut permeability was not altered by Zn deficiency or prebiotic intake in young adult female rats. $\mathrm{Zn}$ deficiency has been previously shown to alter intestinal morphology ${ }^{(21,22)}$, while having no effect on epithelial tight junctions ${ }^{(68)}$ in otherwise healthy rats. On the other hand, $\mathrm{Zn}$ supplementation has been shown to improve gut permeability in malnutrition, diarrhoea and inflammatory bowel disease ${ }^{(23,24,69,70)}$. The present study also demonstrated that long-chain inulin had no effect on gut permeability in healthy rats. Other studies have found an improvement in gut permeability in models of disease with the use of probiotics or symbiotics (mixture of prebiotic and probiotic bacteria) but not prebiotics ${ }^{(71-74)}$. In healthy rats, FOS has been shown to increase intestinal permeability, a marker of mucosal damage ${ }^{(75)}$; however, FOS did not alter intestinal permeability in healthy men ${ }^{(76)}$.

In summary, future research should investigate both systemic (blood, spleen) and gut (PP, MLN) levels of immunity as they may respond differently to dietary treatments. For instance, PRE elevated the proportion of $\mathrm{TCR} \alpha \beta^{+} \mathrm{CD} 4^{+}$ cells in spleen and the ex vivo secretion of IL-2, IL-10 and IFN- $\gamma$ from both spleen and MLN cells, while reducing the number and proportion of $\mathrm{TCR} \alpha \beta^{+} \mathrm{CD} 8^{+}$cells in both spleen and PP, and CD45RA ${ }^{+}$cells in the MLN. Furthermore, ZD had no effect on immune cells in the spleen, while reducing $\mathrm{T}$ cell numbers in the MLN. The present study also found that ZD lowers $\mathrm{TCR} \alpha \beta^{+} \mathrm{CD}^{+}$and $\mathrm{TCR} \gamma \delta^{+}$cell numbers in the gut and that inulin may counteract these effects of ZD. Since TCR $\gamma \delta^{+}$cells are found in abundance in the epithelia of the mucosa, future studies should analyse intra-epithelial lymphocytes. Last, the novel finding of an increased proportion and number of dendritic cells in the PP of inulin-fed rats indicates a need for further research on how prebiotics and their metabolites affect immune function possibly through intestinal dendritic cells.

\section{Acknowledgements}

We thank the staff of the University of Manitoba Animal Holding Facility, Sarah Cahill, Lisa Rigaux, Jennifer Zahradka, Jennifer Jamieson, Steve Wayne, Heather Hosea and Marie Claire Arrieta for their assistance. Funding was provided by the Natural Sciences and Engineering Research Council (NSERC) of Canada and Canada-Manitoba AgriFood Research and Development Initiative grants (C. G. T.) and a NSERC Canada Graduate Scholarship (N. R. R.).

N. R. R. designed the study, analysed the data and wrote the manuscript. C. G. T provided guidance to N. R. R. and edited the manuscript. J. B. M. was responsible for the analysis and interpretation of samples collected for gut permeability.

All authors declare no conflicts of interest.

\section{References}

1. Gibson GR, Probert HM, Rastall R, et al. (2004) Dietary modulation of the human colonic microbiota: updating the concept of prebiotics. Nutr Res Rev 17, 259-275.

2. Kleessen B, Hartmann L \& Blaut M (2003) Fructans in the diet cause alterations of intestinal mucosal architecture, released mucins and mucosa-associated bifidobacteria in gnotobiotic rats. Br J Nutr 89, 597-606.

3. Roller M, Rehkemmer G \& Watzl B (2004) Prebiotic inulin enriched with oligofructose in combination with the probiotics Lactobacillus rhamnosus and Bifidobacterium lactis modulates intestinal immune functions in rats. J Nutr 134, 153-156.

4. Roller M, Pietro Femia A, Caderni G, et al. (2004) Intestinal immunity of rats with colon cancer is modulated by oligofructose-enriched inulin combined with Lactobacillus rhamnosus and Bifidobacterium lactis. Br J Nutr 92, 931-938.

5. Manhart N, Spittler A, Bergmeister H, et al. (2003) Influence of fructooligosaccharides on Peyer's patch lymphocyte numbers in healthy and endotoxemic mice. Nutrition 19, 657-660.

6. Hosono A, Ozawa A, Kato R, et al. (2003) Dietary fructooligosaccharides induce immunoregulation of intestinal IgA secretion by murine Peyer's patch cells. Biosci Biotechnol Biochem 67, $758-764$

7. Lindsay JO, Whelan K, Stagg AH, et al. (2006) Clinical, microbiological, and immunological effects of fructooligosaccharides in patients with Crohn's disease. Gut 55, 348-355.

8. Smits HH, Engering A, van der Kleij D, et al. (2005) Selective probiotic bacteria induce IL-10-producing regulatory $\mathrm{T}$ cells in vitro by modulating dendritic cell function through dendritic cell-specific intercellular adhesion molecule 3-grabbing nonintegrin. J Allergy Clin Immun 115, 1260-1267.

9. Kidd P (2003) Th1/Th2 balance: the hypothesis, its limitations, and implications for health and disease. Alt Med Rev 8, 223-246.

10. Benjamini E, Coico R \& Sunshine G (2000) Immunology: A Short Course, 4th ed. New York: John Wiley \& Sons. 
11. Allez M \& Mayer L (2004) Regulatory T cells. Peace keepers in the gut. Inflamm Bowel Dis 10, 666-676.

12. Delzenne N, Aertssens J, Verplaetse H, et al. (1995) Effect of fermentable fructo-oligosaccharides on mineral, nitrogen and energy digestive balance in the rat. Life Sci 57, 1579-1587.

13. Raschka L \& Daniel H (2005) Diet composition and age determine the effects of inulin-type fructans on intestinal calcium absorption in rat. Eur J Nutr 44, 360-364.

14. King JC \& Keen CL (1999) Zinc. In Modern Nutrition in Health and Disease, 9th ed., pp. 223-239 [ME Shils, JA Olso, M Shike and AC Ross, editors]. Hagerstown, MD: Lippincott Williams \& Wilkins.

15. Shankar AH \& Prasad AS (1998) Zinc and immune function: the biological basis of altered resistance to infection. Am J Clin Nutr 68, Suppl. 2, 447S-463S.

16. Ibs KH \& Rink L (2003) Zinc-altered immune function. $J$ Nutr 133, Suppl. 1, 1452S-1456S.

17. Prasad AS, Meftah S, Abdallah J, et al. (1988) Serum thymulin in human zinc deficiency. J Clin Invest 82, 1202-1210.

18. Prasad AS, Beck FWJ, Grabowski SM, et al. (1997) Zincdeficiency: changes in cytokine production and T-cell subpopulations in patients with head and neck cancer and in noncancer subjects. Proc Assoc Am Physicians 109, 68-77.

19. Beck FWJ, Prasad AS, Kaplan IJ, et al. (1997) Changes in cytokine production and $\mathrm{T}$ cell subpopulations in experimentally induced zinc-deficient humans. Am J Physiol 272, E1002-E1007.

20. Bao B, Prasad AS, Beck FWJ, et al. (2003) Zinc modulates mRNA levels of cytokines. Am J Physiol Endocrinol Metab 285, E1095-E1102.

21. Elmes ME \& Jones JG (1980) Ultrastructrual changes in the small intestine of zinc deficient rats. J Pathol 130, 37-43.

22. Mengheri E, Nobili F, Vignolini F, et al. (1999) Bifidobacterium animalis protects intestine from damage induced by zinc deficiency in rats. $J$ Nutr 129, 2251-2257.

23. Sturniolo GC, Fries W, Mazzon E, et al. (2002) Effect of zinc supplementation on intestinal permeability in experimental colitis. J Lab Clin Med 139, 311-315.

24. Sturniolo GC, Di Leo V, Ferronato A, et al. (2001) Zinc supplementation tightens 'leaky gut' in Crohn's disease. Inflamm Bowel Dis 7, 94-98.

25. Baum M, Campa A, Lai S, et al. (2003) Zinc status in human immunodeficiency virus type 1 infection and illicit drug use. Clin Infect Dis 37, Suppl. 2, S117-S123.

26. Ojuawo A \& Keith L (2002) The serum concentrations of zinc, copper and selenium in children with inflammatory bowel disease. Cent Afr J Med 48, 116-119.

27. Griffin IJ, Kim SC, Hicks PD, et al. (2004) Zinc metabolism in adolescents with Crohn's disease. Pediatr Res 56, 235-239.

28. Menne E, Guggenbuhl M \& Roberfroid M (2000) Fn-type chicory inulin hydrolysate has a prebiotic effect in humans. $J$ Nutr 130, 1197-1199.

29. Walker CF \& Black RE (2004) Zinc and the risk for infectious disease. Ann Rev Nutr 24, 255-275.

30. Verghese M, Rao DR, Chawan CB, et al. (2002) Dietary inulin suppresses azoxymethane-induced aberrant crypt foci and colon tumors at the promotion stage in young Fisher 344 rats. $J$ Nutr 132, 2809-2813.

31. Meddings JB \& Gibbons I (1998) Discrimination of site-specific alterations in gastrointestinal permeability in the rat. Gastroenterology 114, 83-92.

32. Meddings JB, Jarand J, Urbanskik SJ, et al. (1999) Increased gastrointestinal permeability is an early lesion in the spontaneously diabetic BB rat. Am J Physiol Gastrointest Liver Physiol 276, 951-957.

33. Field CJ, Goruk S \& Glen S (1999) Effect of diet on the development of the immune system in the BB rat. J Clin Biochem Nutr 26, 119-134.
34. Stillie R, Bell RC \& Field CJ (2005) Diabetes-prone BioBreeding rats do not have a normal immune response when weaned to a diet containing fermentable fibre. Br J Nut 93, 645-653.

35. Brenan M \& Puklavec M (1992) The MRC OX-62 antigen: a useful marker in the purification of rat veiled cells with the biochemical properties of an integrin. J Exp Med 175, 1457.

36. Clegg MS, Keen CL, Lonnerdal B, et al. (1981) Influence of ashing techniques on the analysis of trace elements in animal tissues. Biol Trace Elem Res 3, 107-115.

37. Viney JL, Mowat AM, O’Malley JM, et al. (1998) Expanding dendritic cells in vivo enhances the induction of oral tolerance. J Immunol 160, 5815-5825.

38. Makala LH, Nishikawa Y, Suzuki N, et al. (2004) Immunology. Antigen presenting cells in the gut. J Biomed Sci 11, 130-141.

39. Smits HH, Engering A, van der Kleij D, et al. (2005) Selective probiotic bacteria induce IL-10-producing regulatory $\mathrm{T}$ cells in vitro by modulating dendritic cell function through dendritic cell-specific intercellular adhesion molecule 3-grabbing nonintegrin. J Allergy Clin Immunol 115, 1260-1267.

40. Kelly-Quagliana KA, Nelson PD \& Buddington RK (2003) Dietary oligofructose and inulin modulate immune functions in mice. Nutr Res 23, 257-267.

41. Hosea HJ, Rector ES \& Taylor CG (2003) Zinc-deficient rats have fewer recent thymic emigrant $(\mathrm{CD} 90+) \mathrm{T}$ lymphocytes in spleen and blood. $J$ Nutr 133, 4239-4242.

42. Holtmeier W \& Kabelitz D (2005) $\gamma \delta \mathrm{T}$ cells link innate and adaptive immune responses. Chem Immunol Allergy 86, 151-183.

43. Kolida S, Tuohy K \& Gibson R (2002) Prebiotic effects of inulin and oligofructose. Br J Nutr 87, Suppl. 2, S193-S197.

44. Lee J, Mo JH, Katakura K, et al. (2006) Maintenance of colonic homeostasis by distinctive apical TLR9 signalling in intestinal epithelial cells. Nat Cell Biol 8, 1327-1336.

45. Pestka JJ, Ha CL, Warner RW, et al. (2001) Effects of ingestion of yogurts containing Bifidobacterium and Lactobacillus acidophilus on spleen and Peyer's patch lymphocyte populations in the mouse. J Food Prot 64, 392-395.

46. Perdigon G, Vintini E, Alvarez S, et al. (1999) Study of the possible mechanisms involved in the mucosal immune system activation by lactic acid bacteria. J Dairy Sci 82, 1108-1114.

47. Bornet F, Brouns F, Tashiro Y, et al. (2002) Nutritional aspects of short-chain fructooligosaccharides: natural occurrence, chemistry, physiology and health implications. Dig Liver Dis 34, Suppl. 2, S111-S120.

48. Cavaglieri CR, Nishiyama A, Fernandes LC, et al. (2003) Differential effects of short-chain fatty acids on proliferation and production of pro- and anti-inflammatory cytokines by cultured lymphocytes. Life Sci 73, 1683-1690.

49. Nancey S, Bienvenu J, Coffin B, et al. (2002) Butyrate strongly inhibits in vitro stimulated release of cytokines in blood. Dig Dis Sci 47, 921-928.

50. Säemann MD, Böhmig GA, Osterreicher CH, et al. (2000) Anti-inflammatory effects of sodium butyrate on human monocytes: potent inhibition of IL-12 and up-regulation of IL-10 production. FASEB $J$ 14, 2380-2382.

51. Novogrodsky A, Rubin AL \& Stenzel KH (1980) A new class of inhibitors of lymphocyte mitogenesis: agents that induce erythroid differentiation in Friend leukemia cells. J Immunol 124, 1892-1897.

52. Bohmig GA, Csmarits B, Cerwenka A, et al. (1995) Induction of alloantigen-specific hyporesponsiveness in vitro by the short-chain fatty acid N-butyrate. Transplantation 59, $1500-1503$.

53. Kyner D, Zabos P, Christman J, et al. (1976) Effect of sodium butyrate on lymphocyte activation. J Exp Med 144, 1674-1678.

54. Eftimiadi C, Valente S, Mangiante S, et al. (1995) Butyric acid, a metabolic end product of anaerobic bacteria, inhibits B-lymphocyte function. Minerva Stomatol 44, 445-447. 
55. Sakata T (1997) Butyrate and the colonocyte. In Advances in Experimental Medicine and Biology, vol. 427: Dietary Fiber in Health and Disease [D Kritchevsky and C Bonfield, editors]. New York: Plenum Press.

56. Tokunaga $T$, Oku $T$ \& Hosoya $N$ (1986) Influence of chronic intake of new sweetener fructooligosaccharide (Neosugar) on growth and gastrointestinal function of the rat. J Nutr Sci Vitaminol 32, 111-121.

57. Ohta A, Yasuko M, Ohtsuki M, et al. (1998) Dietary fructooligosaccharides change the concentration of calbindin-D9k differently in the mucosa of the small and large intestine of rats. J Nutr 128, 934-939.

58. Brown GD \& Gordon S (2001) A new receptor for $\beta$-glucans. Nature 413, 36-37.

59. Herre J, Gordon S \& Brown GD (2004) Dectin-1 and its role in the recognition of $\beta$-glucans by macrophages. Mol Immunol 40, 869-876.

60. Watzl B, Girrbach S \& Roller M (2005) Inulin, oligofructose and immunomodulation. Br J Nutr 93, S49-S55.

61. Coudray C, Feillet-Coudray C, Gueux E, et al. (2006) Dietary inulin intake and age can affect intestinal absorption of zinc and copper in rats. J Nutr 136, 117-122.

62. Beach RS, Gershwin ME \& Hurley LS (1983) Persistent immunological consequences of gestation zinc deprivation. Am J Clin Nutr 38, 579-590.

63. Prasad AS (2007) Zinc: mechanisms of host defense. $J$ Nutr 137, 1345-1349.

64. Hosea HJ, Rector ES \& Taylor CG (2004) Dietary repletion can replenish reduced $\mathrm{T}$-cell subset numbers and lymphoid organ weight in zinc-deficient and energy-restricted rats. Br J Nutr 91, 741-747.

65. Hosea HJ, Rector ES \& Taylor CG (2008) Altered ex vivo cytokine production in zinc-deficient, pair-fed, and marginally zinc-deficient growing rats is independent of serum corticosterone concentrations. Br J Nutr 100, 820-828.

66. Szczurek EI, Bjornsson CS \& Taylor CG (2001) Dietary zinc deficiency and repletion modulate metallothionein immunolocalization and concentration in small intestine and liver of rats. J Nutr 31, 2132-2138.

67. Hosea HJ, Rector ES \& Taylor CG (2007) Dietary zinc deficiency lowers the proportion of splenic CD90 (Thy-1) $\mathrm{B}$-cells and late thymic emigrant $\mathrm{T}$-cells in growing rats. Br J Nutr 98, 1108-1111.

68. Moran JR \& Lewis LC (1985) The effects of severe zinc deficiency on intestinal permeability: an ultrastructural study. Pediatr Res 19, 968-973.

69. Roy SK, Behrens RH, Haiders R, et al. (1992) Impact of zinc supplementation on intestinal permeability in Bangladeshi children with acute diarrhoea and persistent diarrhoea syndrome. $J$ Pediatr Gastroenterol Nutr 15, 289-296.

70. Rodriguez P, Darmon N, Chappuis P, et al. (1996) Intestinal paracellular permeability during malnutrition in guinea pigs: effect of high dietary zinc. Gut 39, 412-422.

71. Commane DM, Shortt CT, Silvi S, et al. (2005) Effects of fermentation products on pro- and prebiotics on trans-epithelial electrical resistance in an in vitro model of the colon. Nutr Cancer 51, 102-109.

72. Olguin F, Araya M, Hirsch S, et al. (2005) Prebiotic ingestion does not improve gastrointestinal barrier function in burn patients. Burns 31, 482-488.

73. Bai AP \& Ouyang Q (2006) Probiotics and inflammatory bowel disease. Postgrad Med J 82, 376-382.

74. Spindler-Vesel A, Bengmark S, Vovk I, et al. (2007) Synbiotics, prebiotics, glutamine, or peptide in early enteral nutrition: a randomized study in trauma patients. J Parenter Enteral Nutr 31, 119-126.

75. Ten Bruggencate SJ, Bovee-Oudenhoven IM, Lettink-Wissink ML, et al. (2005) Dietary fructooligosaccharides increase intestinal permeability in rats. $J$ Nutr $\mathbf{1 3 5}, 837-842$.

76. Ten Bruggencate SJ, Bovee-Oudenhoven IM, LettinkWissink ML, et al. (2006) Dietary fructooligosaccharides affect intestinal barrier function in healthy men. J Nutr 136, $70-74$. 